\title{
Sociopolitical Challenges of Afghan Society: Post 9/11 Scenario
}

\author{
Muhammad Ahad Yar Khan \\ University of Karachi, Area Study Centre for Europe \\ Tansif ur Rehman \\ University of Karachi, Department of Criminology
}

Received 23 October 2018 • Revised 30 November 2018 • Accepted 12 December 2018

\begin{abstract}
Purpose of the Research: The article examines various issues in Afghanistan in the context of post- 9/11 scenario. It focuses on security, maintenance as well as various development pursuits encompassing the social, political, and economic dimensions of Afghanistan.

Method: The respective study is qualitative and secondary academic sources have been used. Conclusion: The process of rehabilitation in Afghanistan is directly connected with Pakistan. Pakistan with the cooperation of China is heading for such projects that will unquestionably benefit the whole region, especially Afghanistan. Gwadar port and China-Pakistan Economic Corridor project will open the doors for landlocked Afghanistan. On the other hand, Afghanistan is gateway for Pakistan to the Central Asian countries, which possess abundance of natural resources that can be of great use for Pakistan in the near future. Moreover, to fight the common foe, i.e., terrorism, both countries need cooperation on intelligence and strategic level.
\end{abstract}

Keywords: Afghanistan, Pakistan, sociopolitical challenges, post-9/11, qualitative.

\section{Introduction}

Pakistan and Afghanistan share a 2,240 km border known as the Durand Line, and since 1893 it has divided the region of Pashtun and Baloch ethnic groups' majority into two countries. As immediate neighbors, Pakistan and Afghanistan have religious and ethnic resemblances, but unfortunately the relation between the two countries have never been smooth. A secure and calm border at the Afghanistan side is always in the national interest of Pakistan, having historical and traditional rivalry with India at the eastern borders. But, the unpleasant condition on both sides of the country made it a pincer movement for Pakistan (Durani \& Khan, 2002).

Pakistan is unable to enjoy a peaceful and secure border with Afghanistan except the period of religious rule in Afghanistan known as the Taliban era from 1996 to 2001. Different Afghan governments have always shown disaffection towards Pakistan. While, the core issues are always the Durand Line and the Pashtun belt, which Afghanistan wishes to govern as around two

(C) Authors. Terms and conditions of Creative Commons Attribution 4.0 International (CC BY 4.0) apply. Correspondence: Dr. Tansif ur Rehman, Teaching Associate, Department of Criminology, University of Karachi-75270, PAKISTAN. E-mail: Tansif@live.com. 
and a half centuries ago these areas were ruled by Ahmad Shah Durrani, also known as Ahmad Khan Abdali (Burke \& Ziring, 1991).

- Better Pak-Afghan relation will bring peace in the region.

- Pakistan and Afghanistan can become economically stable.

- Pakistan and Afghanistan need to be attentive of their policies.

- Foreign powers can try to sabotage all attempts for a cordial relation.

- External influences can jeopardize Pak-Afghan interest in short and long-run.

The relations between Pakistan and Afghanistan are more complex due to the similarities both sides inherit. Islam is the religion of the majority of Pakistan as well as Afghanistan, and ethnic groups like Pashtun and Baloch who have identically similar language and culture (Malik, 2008).

However, the particular region has never been fully ruled by any of the government. These cultural and geographical conditions helped the United States of America and its allies to use the border area to combat the Union of Soviet Socialist Republics (USSR) in the past and thus intersecting both sides of the respective border according to strategic needs (Kakar, 1997).

Before the emergence of Taliban in Afghanistan in the decade of 9os, i.e. right after the Soviet Union's exit, the fight among local groups intensified towards the completed destruction of Afghanistan. However, the Taliban regime was toppled by America along with its allies and the region again gained world focus as the toppled power and its supporters used the specific land to reorganize and fight back the American forces along with attacking the border areas (Fair, Howenstein \& Thier, 2006).

The particular situation of the war zone made it possible to be considered as the safe heaven for the insurgents, which enhanced the difficulties of traditional war in the Pashtun belt. When it comes to Pakistan, the international powers pressurize Pakistan to "do more", i.e., to eliminate insurgencies on both sides of the border. Consequently, the situation on the ground continued after several efforts and both countries held each other responsible for insurgencies in their territory.

\section{War against terror}

As the international political scenario changed after 9/11, Pakistan as a front-line state was under a huge pressure to take a "U-turn" in its policies for neighboring countries and Afghanistan in particular. Pakistan had to stop political and diplomatic support of the Afghan government of Taliban. As a state, Pakistan ensured the international community to fight against terrorism and rehabilitation of the region. Thus, Pakistan had played a significant role in the rehabilitation of Afghanistan. On demand of the international community over cross border terrorism, Pakistan increased the number of troops up to eighty thousand at the Afghan borders (Grare, 2006).

As the attacks in Afghanistan continued, the Afghan political regime blamed Pakistan for not doing demanded efforts to stop infiltrators crossing the border line from Pakistan and targeting it and international forces. International political observers were also indicating the viewpoint that toppled the Afghan regime of Taliban and Al-Qaeda along with their top leadership hiding themselves and operating the insurgent activities from 'safe' heaven (Tarzi, 2006).

Far beyond this "safe" heaven allegation, Afghanistan even blamed Inter-Services Intelligence (ISI), i.e., Pakistan's top security agency that an insurgent force in the region and especially the Taliban were supported by ISI as it was providing them strategic support. It became more expressive and intense when top political leadership in Afghanistan blamed the Pakistani 
security agency for involving in an attack on the Indian embassy in Kabul which caused huge damages not only as a direct effect on Afghanistan, but also deteriorated the relations between Pakistan and Afghanistan. In this attack, there were a number of casualties reported and Afghanistan held the ISI directly responsible for all the distractions and anxiousness in Afghanistan. Similarly, a day earlier when the NATO forces came under attack and several of the NATO soldiers were killed, Afghanistan blamed Pakistan for these attacks (Khan, 2008).

Pakistan has always denied such allegations, as a peaceful and prosperous neighboring country is in vast favor of Pakistan and denied any connection to the insurgency in Afghanistan. Syed Yousaf Raza Gillani, a newly elected Prime Minister of Pakistan in 2008 came forward with a reasoning for denial of any insurgency in Afghanistan and stated that peaceful Afghanistan was in the great interest of Pakistan rather than the disturbed one. He often expressed his concerns regarding the Afghan leadership's blame game that it may distract the peace process in the region. The official statements from Pakistan's foreign office also denied the charges and urged Afghanistan not to blame Pakistan in the future without any concrete evidence.

\section{Emancipation}

There are around three million Afghan refugees in Pakistan who regularly travel to their homeland and this is humanly impossible to identify between an Afghan national and a terrorist. Relatively, Pakistan has been asking Afghanistan and the international forces that are present there to control the situation in the Afghan region, and without having control in the Afghan territory, allegations on Pakistan are not more than an attempt to obliterate the incompetence and the failure of the allied forces (Qarabaghi, 2005).

The failure is actually of Afghanistan's administrative incapability to assure a solution. They rather endeavor to create an impression to the world that for all what happen, actually "misshapen" in Afghanistan is the sole responsibility of Pakistan.

The violation of international border laws by forces in Afghanistan had a disastrous effect on the relationship with Pakistan. Pakistan considers it as a blazing assault on its sovereignty. The weak Afghanistan government could not put an embargo to the allied forces in their territory and Afghanistan gave a freehand to the international actors not only to its land, but also to strike its neighbor, i.e. Pakistan. Afghanistan policies have weakened the Pak-Afghan relation altogether.

National interests of both the countries emphasize on the main objective to fight terrorism in the region via helping each other and respecting the sovereignty of their neighbor. Thus, securing each others' interests from the insurgents.

\section{Indian influence}

The relations between Pakistan and India in the context of Afghanistan are often considered as a useless business, because whatever is considered as an achievement of Pakistan is only what India loses there, while what Pakistan loses is what India achieves. After the 9/11 incident, India has used the changed circumstances in its favor and modified its political and diplomatic goals. India has used the scenario to strengthen its influential lobbies and groups in Afghanistan. Almost in all important cities of Afghanistan, India has set up diplomatic missions to weaken Pakistan's interests.

Pakistan has been officially addressing its concerns over the Indian's suspicious activities near its border. Pakistan has officially shown concerns regarding India for printing 
forged Pakistani currency at a large scale to weaken the Pakistani economy and direct support of its ongoing operations involving terrorist activities in Pakistan.

Geographically closed cities of Afghanistan to the Pakistani borders have been used by India to create an anti-state terrorist network in Pakistan along with terrorist camps in the provinces of Helmand, Panjshir, Nimruz, and many other areas. Even the name of Afghan military base camps near Kabul was listed in Pakistan's allegations of Indian involvement to destabilize the region's peace for their political goals (Grare, 2006).

For the burning situation of Balochistan, Pakistan holds India responsible for militancy in its largest province along with the northern areas of Pakistan, including the province of Khyber Pakhtunkhwa (KPK) and Federally Administered Tribal Areas (FATA). On 13 August 2004, Jam Mir Mohammad Yousaf Aliani, the Chief Minister of Pakistan's largest province Balochistan expressed his concerns that, the Indian security agency Research and Analysis Wing (RAW) up holds more than forty terrorists training camps in Balochistan (Ibid.).

Pakistan accused India of provoking and supporting terrorist organizations in Waziristan valley where the Pakistani army was fighting with Al-Qaida and Tehrik-i-Taliban Pakistan (TTP). Pakistan clearly mentioned that terrorist organizations like TTP and others have been provided a direct support in terms of money, ammunition, and tactical guidance by the Indian consulate in southern Afghanistan.

Similarly, the Chairman of Standing Committee on Foreign Affairs expressed in July 2006 that, the nexus of Afghan intelligence agency, i.e., the National Directorate of Security (NDS), and RAW was provoking the Baloch anti-state militancy, and as a result more than 600 Baloch and many members of the Balochistan Liberation Army (BLA) were trained by these respective agencies (Ibid.).

The non-regional powers in Afghanistan have used the Afghan land to control the regional power game, and Pakistan's territory as well as sovereignty has been often violated. Such foreign actors severely affected Pakistan's trust in Afghanistan. Thus, the war against terror in the shared border territory couldn't reach to a macro-level success. If Afghanistan manages to handle this issue and prevent foreign elements from sabotaging, then Pakistan's confidence in Afghanistan will certainly increase. After that, both countries can take security measures in a much better way. If Pakistan gains its confidence back, then it will surely tone up the process of rehabilitation of Afghanistan.

As compared with India, Afghanistan's relations with Pakistan have more significance and should be given more attention to enjoy peace on either side of the borders. Regional peace and long-term interests of the two countries are directly connected with Afghanistan's foreign policies, especially towards Pakistan. Pak-Afghan relationship can only be strengthened by cooperation, while Afghan-Indian nexus for supporting anti-Pakistan activities will undermine the aspiration of betterment in regional rehabilitation.

Realizing the geographical conditions of the region where India does not have any border connected with Afghanistan, but Pakistan has more than two thousand kilometers long shared border with Afghanistan. Afghanistan will need an undisturbed and cooperative neighborhood when international powers will vacate, and then a cordial relation with Pakistan will save Afghan interest more effectively. On the other side, Pakistan has to find possibilities to fortify relations with Afghanistan on the diplomatic front.

\section{Afghan exiles element}

Around three million of Afghan exiles in Pakistan after the Soviet war, and it is also an important element between the two countries' relationship as Pakistan provided them 
accommodation. Most of these refugees have never left Pakistan and are still living here. This provides Pakistan a moral whip hand, as in the early twentieth century Afghanistan refused to open their borders for asylum seekers during the Tehrik-e-Khilafat in the Subcontinent.

A fresh influx of refugees knocked Pakistan when the United States of America along with its allies invaded Afghanistan after 9/11. The Afghan started leaving their homeland due to drought in some parts of the country and feared of a fresh war right after bearing the long civil war (Hussein, 2002). But, this time Pakistan couldn't welcome this new wave due to the reasonable causes of economic and political issues as unlike the previous scenario. This Afghan exiles inflow had to be hosted by Pakistan alone.

The existence of some militants cannot be brushed aside, involved in the cross-border, anti-government activities that creates several long-term difficulties for Pakistan and Afghanistan. The Afghan government considers this as Pakistan's mishandling that allows militants to cross the border, while Pakistan has always categorically stated that it has performed its responsibilities to check and filter out such elements (Nuri, 2007).

\section{Territorial issues}

Pak-Afghan relations have often been severely deteriorated due to their border issues. On the issue of the Durand Line, Afghanistan, even controverted Pakistan's membership in the United Nations. The Durand Line remains the bone of contention between Pakistan and Afghanistan till the Soviet Union invaded Afghanistan in 1979.

However, with respect to a huge number of refugees towards Pakistan and striking change in Afghan internal politics, the issue of the Durand Line with Pakistan got hibernated. This hibernation continued after the Soviet Union left Afghanistan in 1989, and a conservative Taliban government continued. But, after the pro-American government was established in Afghanistan, the issue of the Durand Line resurged as Hamid Karzai's cabinet awakened controversial and dormant territorial issues.

The cross-border terrorism echoed the international community and mass media. To get rid of this particular issue, in early Spring 2006 Pakistan's Interior Ministry officially offered to seal its borders with Afghanistan. Then interior minister Aftab Shair Pao even proposed to land mine the respective border by using tactically advance military practices with reference to its rivalry with India, which made both of the country world experts at it.

The Durand Line was actually a single-page agreement and seven short articles between Sir Mortimer Durand from British India and King Abdul Rehman Khan of Afghanistan on 12 November 1893 (Smith, 2004). Afghanistan rejected all offers from Pakistan and arrogated that the Durand Line was not an international border, thus could never be treated alike. Afghanistan's stance over Durand Line was exposed influence by non-regional powers that intent to damage Pakistan's interest in the region and accomplishing their own agenda.

The Pakistani declaration of the Durand Line as a recognized and an established international boundary that the distinguished two counties has also been acknowledged by Afghanistan at various occasions. Moreover, Pakistan's stance for Durand Line is quite justifiable that no agreement shall be believed or considered legal among sovereign countries until both of the entities approve or agree upon (Grare, 2006).

The treaty between King Abdul Rehman Khan and Sir Mortimer Durand was signed in a well-disposed environment, as the King in his address to Afghan tribal leaders having political and military powers summarized the understanding of the treaty and totaled the outlook of Durand Line arrangements. He advised Afghan lords to a candid adherence to the British alliance and clearly mentioned that Afghanistan by the Durand line has demarcated its proper boundary 
to prevent from any future misunderstanding. The King adapted the Durand Line as the security line that would fortify Afghanistan.

If Afghanistan and Pakistan are able to settle down the Durand Line issue, then a serious concern in a bilateral relation will be removed. It will be a significant measure for both the countries to develop a long-term, friendly relation and to accelerate the process of rehabilitation. Resolving the Durand Line issue will also help the parties to resolve major issues of the region. The historical commitment and adherence to the international law will help Afghanistan shutting down the issue in a great sense.

\section{The border seal issue between Pakistan and Afghanistan}

The Durand Line is almost 2,240 km long. The cost of setting up a barbed wire fence along the border would be in millions, and even this cannot stop people from crossing it. Watchtowers and check posts are needed, if the watchtowers are built after every two km then at least 1,120 watchtowers are required. For instance, check post is built after every ten km, so it sums up to 224 check posts. Additionally, the landscape of Durand Line is very treacherous and unforgiving. Transporting raw materials and labor work force to build these would be a very difficult job as there are no roads.

Even after setting up the barbed wire, check posts and watchtowers, the next step would be to establish a new Army unit or Force that can guard it. Pakistan Army is very busy in combating internal terrorism and securing our border on the eastern front. So, it will be a tough job for the Army to deploy a unit or brigade on these borders and new recruitments will also be required.

If the army somehow pulled it off, then the problem arises that the respective soldiers will need supplies, i.e., food and ammunition. Delivering supplies to the soldiers will also be really difficult because of the terrain. The army would need to build new roads to tackle the problem or they would require helicopters for supplies. If the army decides to build roads, then it would be a long-term solution which would require years to complete and if it decides to take the second way out then a new aviation crew would be required. In both cases the expenses would be enormous.

If we add up all the operational, maintenance cost and manpower required, it would not be feasible for Pakistan to initiate such a mega-project because of economic issues. The terrain is very rough and if a check post is attacked, it would take hours before backup forces could reach which would result in either loss of life or territory.

\section{Social issues in Afghanistan}

\subsection{Opium cultivation}

Afghanistan has been the world's largest opium producer, i.e., ahead of Myanmar and Latin America since 1992. Opium production in Afghanistan has been on the rise since U.S. occupation in 2001. Based on UNODC data, more land is now used for opium in Afghanistan than is used for coca cultivation in Latin America. Afghanistan is also the largest producer of cannabis (mostly hashish) in the world Helmand is the largest province in Afghanistan with regards to opium production (Nawa, 2011).

\subsection{Child labor in Afghanistan}

According to the Government of Afghanistan, the Central Statistics Organization report (2013), at least a quarter of Afghan children between ages 5 and 14 work for a living or to 
help their families. Children in Afghanistan generally work long hours with little or no pay. They work in the home-based carpet industry; as bonded labor in brick kilns; in the metal industry as tinsmiths and welders; in mines; in agriculture; and on the streets as vendors, shoe shiners, and beggars.

Landlessness, illiteracy, high unemployment, continuing armed conflict in much of the country, and a corresponding lack of able-bodied male adult workers in many families are among the most important factors contributing to chronic poverty and, by extension, child labor (Nilsson, 2013).

\subsection{Child health in Afghanistan}

According to the report of a Swiss organization (Humanium, 2017), people living in Afghanistan today have a limited number of medical facilities. They would have to travel for hundreds of kilometers for the treatment due to which many of severe patients faces death.

Another dilemma lies with the very fact that the medical officers also lack proper training and they do not have even appropriate equipment for a checkup and treatment of the respective patients. About $70 \%$ of the population does not have access to drinking water, which is a major cause of health problems, especially among young children.

\subsection{Child education in Afghanistan}

Humanium (2017) further claims that, the total literacy rate in Afghanistan is hardly around $38 \%$. Only $60 \%$ of the children are sent to school for studies. The education system even lacks infrastructure. In Kabul, the schools are so small that in many of the schools a single class holds 60 students, which is creating a problem for every single student.

Afghanistan has the highest ratio of terrorist attacks mostly targeted at schools, especially girls' school. Progress has to be ensured regarding the security of students as Afghans are afraid to send their children to schools because of threats by extremists. The government should ensure the right of education for every Afghan child, which it has failed to do so.

\subsection{Women rights in Afghanistan}

After the continuous attacks of Taliban regarding women's rights in the past, women living in Afghanistan are still suffering abuse as well as extreme oppression. A research conducted by Global Rights estimates that around 90\% of the women in Afghanistan are facing psychological and physical violence, and are often forced into child marriages as well as forced marriages.

Most of the time it is seen that the physical abuse is performed by the most trustworthy people, i.e., their family. Even though some organizations are trying their best to provide protection and legal assistance, but it is unsatisfactory on the macro level. Most of the women have to return to their homes in the absence of such alternative and after that they have to face more of these domestic problems. Some are even bound to take drastic measures like self-immolation.

To a great extent Islamic fundamentalism has influenced the Afghan government's policies. Alarming suicide rates of Afghan females are often the result of forced marriages. Thus, in comparison with women in other countries and their male counterparts Afghan women are facing a very miserable life (Mehta, 2002). 


\section{Conclusion}

As immediate neighbors, Pakistan and Afghanistan must recognize each other significance. Long shared-border countries have ethnic, political, and religious similarities. They must have a friendly relation in order to uphold peace and prosperity. Better Pak-Afghan relation will bring peace and lead this region to fortify with respect, peace and economic stability. A supportive environment will certainly help both countries get rid of many difficulties.

The process of rehabilitation in Afghanistan is directly connected with Pak-Afghan relation. For Afghanistan, Pakistan is the best available opportunity at the door step. Pakistan with the cooperation of its natural ally China is heading for such projects that will unquestionably benefit the whole region, especially Afghanistan. Gwadar port and China-Pakistan Economic Corridor (CPEC) project will open the doors for landlocked Afghanistan.

On the other hand, Afghanistan is the gateway for Pakistan to the Central Asian countries, which possess abundance of natural resources that can be of great use for Pakistan in the near future. It is only possible with Afghanistan's assistance, thus a cordial relation with Afghanistan is even essential for Pakistan.

Moreover, to fight the common foe, i.e., terrorism, both countries need cooperation on intelligence and strategic level, as it cannot be handled alone by any country. By overcoming the Afghan refugees' issue, both countries need to have a constructive dialog for bringing back refugees to their homeland with dignity. Terrorism and the issue of refugees is closely related to each other. It can only be solved by ensuring concrete initiatives rather than accusing each other.

During the Soviet occupation of Afghanistan the drugs business was enhanced in Afghanistan by local and foreign elements. However, during the conservative religious government of Taliban the drug business was successfully prohibited as they put a ban on its cultivation. But, right after the Taliban rule the drug business started again. It is the support system of various criminal activities and is responsible for a lot of social issues in Pakistan and Afghanistan. A mutual combat against it will support ceasing the entire network that causes a great disturbance in the region.

However, Pakistan and Afghanistan need to be attentive of their policies, as the foreign actors will by all odds strike hard for sabotaging all the attempts for a cordial relation and jeopardize the Pak-Afghan interest in the short as well as long-term. Despite everything went wrong the hope is still there.

\section{Recommendations}

1. Afghanistan must strengthen its internal socio-political policies along with its foreign policy.

2. Afghanistan must deploy its experienced and qualified diplomats all over the world.

3. Afghanistan needs to improve its internal as well as external economy.

4. Afghanistan direly needs to resolve all the issues with its neighbors, especially with Pakistan, as these two countries can be natural allies.

5. The United States of America as the superpower must assign a special coordinator to resolve the issues between Afghanistan and Pakistan.

6. Respect as well as the dignity of Afghans must be maintained with due regard to the religious and cultural context in Pakistan and vice versa.

7. International organizations and UN specialized agencies should assist Afghanistan to lead it towards development.

8. Special attention must be paid towards children and women's rights in Afghanistan. 
9. As there is a high risk of insecurity, therefore effective humanitarian interventions are needed in the long run.

10. Indian intervention in Afghanistan has deteriorated Pak-Afghan relations and the global image of Afghanistan, thus the blame game should be immediately stopped, thus ensuring a healthy relationship.

\section{Acknowledgements}

This research did not receive any specific grant from funding agencies in the public commercial, or not-for-profit sectors.

The authors declare no competing interests.

\section{References}

Burke, S. M., \& Ziring, L. (1991). Pakistan's foreign policy: An historical analysis ( ${ }^{\mathrm{nd}} \mathrm{ed}$.). Karachi: Oxford University Press.

Durani, M. U., \& Khan, A. (2002). Pakistan-Afghan relations: Historic mirror. The Dialogue, 4(1), 25-61.

Fair, C. C., Howenstein, N., \& Thier, J. A. (2006). Trouble on the Pakistan-Afghanistan border. Retrieved from http://www.usip.org/pubs/usipeace briefings/2006/1207 pakistan afghanistanborder.html.

Government of Afghanistan: Central Statistics Organization (2013). Afghanistan Multiple Indicator Cluster Survey. Retrieved from http://cso.gov.af/Content/files/AMICS.pdf.

Grare, F. (2006). Pakistan Afghanistan relations in the post-9/11 era. Carnegie Papers, Carnegie Endowment for International Peace, South Asia Project, No. 72, 9-12.

Humanium (2017). Children of Afghanistan: Realizing children's rights in Afghanistan. Retrieved from http://www.humanium.org/en/asia-pacific/afghanistan/

Hussein, R. (2002). Pakistan's relations with Afghanistan: Continuity and change. Strategic Studies, 22(4).

Kakar, H. (1997). Afghanistan: The Soviet invasion and the Afghan response, 1979-1982. Berkeley, CA: University of California Press.

Khan, A. A. (2008). Responding to Kabul. Retrieved from http://www.nation.com.pk/pakistan-newsnewspaper-daily-englishonline/Opinions/Columns/23-Jul-2008/Responding-to-Kabul.

Malik, H. (2008). US relations with Afghanistan and Pakistan: The imperial dimension. London: Oxford University Press.

Mehta, S. (Ed.). (2002). Women for Afghan women: Shattering myths and claiming the future. New York: St. Martin's Griffin.

Nawa, F. (2011). Opium nation: Child brides, drug lords, and one woman's journey through Afghanistan. New York: Harper Perennial.

Nilsson, A. C. (2013). Children and youth in armed conflict. Leiden, Netherlands: Martinus Nijhoff Publishers.

Nuri, M. H. (2007). Pak-Afghan relations: Way out of impasse? IPRI Journal, 7(1).

Qarabaghi, J. (2005). The squandered goodwill: The blame game and what has to be done. The Afghan Observer. Retrieved from http://afghanobserver.com/Articles/Qarabaghi_BlameGame.htm. 
M. A. Y. Khan \& T. Rehman - Sociopolitical Challenges of Afghan Society: Post 9/11 Scenario

Smith, C. (2004). A selection of historical maps of Afghanistan - The Durand Line. United $\quad$ States: Library of Congress.

Tarzi, A. (2006). Afghanistan: Kabul's new strategy focuses on Pakistan. Retrieved from https://www.rferl.org/a/1069736.html. 